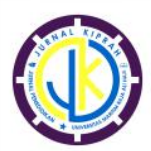

\title{
Kelas Semiotik Nilai Pendidikan Karakter terhadap Masyarakat dalam Karya Raja Ali Haji
}

\author{
Isnaini Leo Shanty ${ }^{1}$, Abdul Malik ${ }^{2}$, Gatot Subroto ${ }^{3}$ \\ ${ }^{1,2,3}$ Universitas Maritim Raja Ali Haji, Tanjungpinang, Kepulauan Riau 29124, Indonesia \\ Pengiriman: 6 Agustus 2019; Diterima: 8 Agustus 2019; Publikasi: 18 November 2019
}

\begin{abstract}
Abstrak
Penelitian ini bertujuan untuk menemukan kelas semiotik nilai pendidikan karakter terhadap masyarakat dalam karya Raja Ali Haji. Lima karya Raja Ali Haji, yaitu Syair Abdul Muluk, Gurindam Dua Belas, Thamarat alMuhimmah, Tuhfat al-Nafis, dan Syair Gemala Mestika Sinar Alam dianalisis sesuai dengan tujuan itu. Dari penelitian ini ditemukan empat kelas semiotik nilai pendidikan budi pekerti terhadap masyarakat: (1) qualisign ikonik rhematik, yaitu kualitas pikiran, perasaan, sifat, dan sikap yang melekat pada orang yang memiliki budi pekerti itu, (2) sinsign indeksikal rhematik, yaitu kualitas perkataan dan atau perilaku seseorang yang dapat didengar dan atau diamati oleh orang lain, (3) legisign indeksikal dicent, yaitu tanda yang bermakna informasi dan merujuk kepada subjek informasi berdasarkan norma tertentu, dan (4) argumen, yaitu simpulan yang dikemukakan oleh Raja Ali Haji berdasarkan kebenaran yang diyakininya, yakni norma ajaran Islam. Berdasarkan temuan tersebut, karya-karya Raja Ali Haji dapat dijadikan rujukan untuk pengembangan materi pendidikan karakter yang bersumber dari karya sastra.
\end{abstract}

Kata kunci: kelas semiotik; indeks; nilai; pendidikan karakter; masyarakat

\section{Abstract}

This research is aimed to find out semiotic classes of character education values to the people in the works of Raja Ali Haji. Five works of Raja Ali Haji, namely Syair AbdulMuluk, Gurindam Dua Belas, Thamarat al-Muhimmah, Tuhfat al-Nafis, and Syair Sinar Gemala Mestika Alam were analyzed. In this research, four semiotic classes of character education values to the people were found: (1) rheumatic iconic qualisign, namely the quality of thoughts, feelings, traits, and attitudes attached to people who have that character, (2) rheumatic indexical sinsign, namely the quality of words and or behavior of someone that can be heard and or observed by others, (3) dicent indexical legisign, which is a sign that is meaningful information and refers to the subject of information based on certain norms, and (4) argumen, namely the conclusions put forward by Raja Ali Haji is based on the truth he believes, namely the norms of Islamic teachings. Based on these findings, Raja Ali Haji's works can be used as references for the development of character education material sourced from literary works.

Keywords: semiotic class; index; value; character education; people

\section{Pendahuluan}

Raja Ali Haji rahimahullah (18091873) adalah penulis yang masyhur di antara para intelektual Kesultanan Riau-Lingga pada abad ke-19 (Malik, 2008; Malik \& Shanty, 2017). Beliau telah menulis dua puluh buku 


\section{JURNAL KIPRAH. November 2019; 7 (2): 71-80 \\ ISSN (online): 2580-6947 \\ ISSN (print): 2354-7278}

dalam pelbagai bidang ilmu, yang terdiri atas bidang bahasa, sastra, filsafat, hukum dan pemerintahan, sejarah, agama Islam, dan pendidikan (Malik, 2015; Malik \& Junus, 2000).

Dalam karya beliau Gurindam Dua Belas, pada Pasal yang Kelima, bait 1, Haji (1846) mengatakan, "Jika hendak mengenal orang berbangsa, lihatlah kepada budi dan bahasa." Kenyataan itu menunjukkan bahwa Raja Ali Haji, sebagai cendekiawan, budayawan, sastrawan, sejarawan, dan pakar agama Islam memandang sangat penting keberadaan budi dan budi pekerti bagi manusia (Malik, 2012b). Akan tetapi, perihal kehalusan budi dan budi pekerti dalam karya beliau belum mendapat perhatian para peneliti dan sarjana. Kajian terhadap karya beliau selama ini lebih banyak terfokus pada bidang agama, linguistik, sejarah, politik, hukum, pemerintahan, dan sastra (Malik, 2015).

Pentingnya kajian ini sejalan dengan kebijakan pendidikan di Indonesia. Sejak 2010 Pemerintah Republik Indonesia telah menerapkan Pendidikan Budi Pekerti. Dengan pendidikan karakter itu, diharapkan dapat diselenggarakan program pendidikan yang menyeluruh dengan memperhatikan kemampuan sosial, watak, budi pekerti, serta kecintaan terhadap budaya dan bahasa Indonesia sehingga instutusi pendidikan dapat mendorong penciptaan hasil didik yang mampu menjawab kebutuhan sumber daya manusia yang berkualitas. Berhubung dengan itu, perlu dipersiapkan bahan pengembangan pendidikan tersebut sesuai dengan Visi Pendidikan Nasional Indonesia (Pusat Kurikulum, 2010). Untuk menunjang program tersebut, karya Raja Ali Haji sangat relevan untuk dikaji, yang pada gilirannya dapat dikembangkan menjadi bahan pembelajaran pendidikan karakter. Hal itu disebabkan oleh karya Raja Ali Haji umumnya mengandungi nilai-nilai luhur budi pekerti yang umumnya diadopsi dari ajaran Islam (Bachmid, 2005).

Kebijakan pendidikan nasional itu menekankan bahwa budaya perlu dikembangkan di setiap satuan pendidikan agar peserta didik tak tercabut dari akar budayanya. Oleh karena itu, pendidikan karakter harus dikembangkan bersamaan dengan penamaan pendidikan nilai, pendidikan moral, dan pendidikan watak. Pendidikan ini bertujuan untuk mengembangkan kemampuan peserta didik dalam membuat keputusan baik-buruk, memelihara apa yang baik, dan mewujudkan kebaikan dalam kehidupan sehari-hari dengan sepenuh hati (Pusat Kurikulum, 2010).

Penelitian ini bertujuan untuk menganalisis kelas semiotik nilai pendidikan karakter terhadap masyarakat dalam karya Raja Ali Haji. Hasil penelitian ini diharapkan dapat memperkaya bahan pembelajaran Pendidikan Budi Pekerti dan Pendidikan Sastra. Di samping itu, dari penelitian ini dapat dilestarikan, dikembangkan, dan dimanfaatkan warisan budaya takbenda (intangible cultural heritage) sebagai pedoman hidup manusia, terutama generasi muda, untuk membentuk karakter mereka.

\section{Konsep Budi dan Budi Pekerti}

Konsep budi berasal dari bahasa Sansekerta yang mengandungi filsafat Hindu (Purucker, Ed., dalam Ahmat, 2001; Osborn \& Van Loon, 1996). Walaupun begitu, dalam budaya Melayu konsep itu mengalami modifikasi. Hal ini karena budaya Melayu berdasarkan ajaran Islam sehingga nilai-nilai Islam-lah yang menjadi rujukan utama konsep budi dalam budaya Melayu-Islam.

Bukhari al-Jauhari menjelaskan perihal budi dalam karyanya Taj al-Salatin (Braginsky, 1994). Penjelasan itu dapat disarikan menjadi empat belas ciri, antara lain, budi merupakan entitas yang paling dekat dengan Allah, asal segala kebenaran yang ditunjukkan oleh Allah, memancarkan cahaya kebenaran ke seluruh tubuh manusia, keberadaannya menyebabkan dapat dibedakan antara yang baik dan yang buruk, membawa kesempurnaan diri dan perbuatan manusia, dan unsur yang wajib ada dalam diri manusia agar tak mendapat celaka.

Menurut Haji (1987), budi memuliakan 
manusia, mencegah manusia berbuat salah, sesuatu yang memungkinkan manusia mendapatkan pengetahuan yang sukar-sukar karena budi itu ibarat cahaya yang terangbenderang. Tempat budi itu di dalam hati yang cahayanya terus memancar naik ke dan mengendalikan otak (pikiran) sehingga manusia dapat membedakan yang benar dengan yang salah dan yang baik dengan buruk. Budi itu juga menjelma ke dalam perilaku. Oleh karena itu, seseorang yang memiliki cahaya budi mendapat kemuliaan dari Allah.

Hati tempat bersemayamnya budi itu semakin jelas terlihat dari asal katanya dalam bahasa Arab. Dalam bahasa Arab, menurut Rahman, Azhar, Sarjono, \& Hafrizal (2010), ada beberapa kata yang mengacu kepada makna 'hati' dalam bahasa Indonesia, tetapi dengan kedalaman makna yang berlapis-lapis. Kata-kata itu adalah qalb yaitu dimensi hati yang terluar, lebih dalam lagi ada fuâd yaitu dimensi hati yang merujuk kepada akal yang mengandungi potensi kecerdasan intelektual, ke dalam lagi ada pula tsaqâfah yaitu dimensi hati yang memiliki kecerdasan rohani, lebih dalam lagi ada $l u b b$ yang mengandungi semua kecerdasan intelektual dan kecerdasan rohani, dan dimensi hati yang terdalam adalah sirr yang mengandungi rahasia kerohanian yang paling dalam.

Hati memiliki dua sisi: yang mengarah kepada kebaikan harus dihidupkan dengan nasihat, tetapi yang terikat kepada dunia harus dimatikan dengan kezuhudan (introspeksi diri). Ada sisi hati (keinginan) yang bersifat Ilahiah dan yang bersifat hewani dan syaitaniah, itulah yang mesti dimatikan. Keinginan manusia juga terbagi kepada dua bagian: keinginan yang mengarah kepada Allah dan surga dan keinginan yang mengarah kepada syaitan dan neraka. Hati yang hidup, kuat, dan mengarah kepada Allah serta surgalah yang mesti dipelihara (Yazdi, 2012).

Perhubungan antara hati dan lapisanlapisannya yang melahirkan budi dapat digambarkan dengan Bagan 1 yang berikut ini.

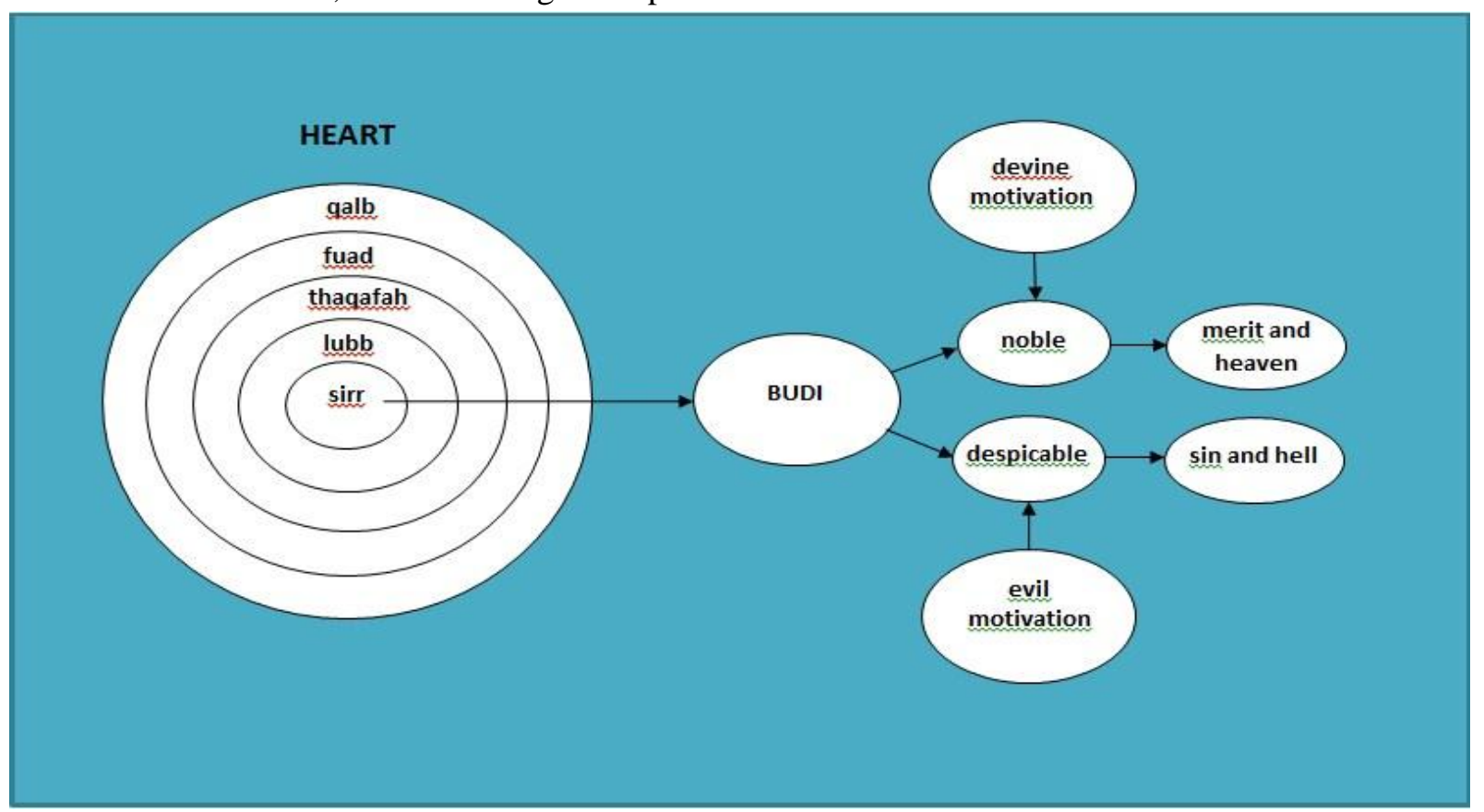

Bagan 1. Hubungan antara hati dan budi (Malik \& Shanty, 2019)

Seperti tergambar pada Bagan 1 di atas, budi yang baik mendatangkan kemuliaan berasal dari keinginan yang bermotivasi Ilahiah. Dalam pada itu, budi yang buruk mendatangkan kehinaan bersumber dari keinginan yang berasal dari dorongan syaitaniah.

Budi pekerti merupakan ungkapan dalam bahasa Indonesia yang juga berasal dari bahasa 
JURNAL KIPRAH. November 2019; 7 (2): 71-80

ISSN (online): 2580-6947

ISSN (print): 2354-7278

Sansekerta. Selanjutnya, kata pekerti berarti 'penampilan, pelaksanaan, aktualisasi, tabiat, dan atau perilaku'. Dengan demikian, secara etimologis budi pekerti berarti 'perilaku atau penampilan diri yang berbudi' (Malik, 2012a).

Berdasarkan pendekatan etika, budi pekerti adalah watak atau tabiat khusus seseorang untuk berbuat sopan dan menghargai pihak lain yang tercermin dalam perilaku dan kehidupannya. Watak itu merupakan keseluruhan dorongan, sikap, keputusan, kebiasaan, dan nilai moral yang baik pada diri seseorang, yang tercakup dalam satu istilah kebajikan (Zuriah, 2008).

Budi pekerti berkaitan dengan akhlak. Istilah akhlak adalah bentuk jamak yang berasal dari kata khuluq dalam bahasa Arab yang bermakna 'adat kebiasaan, perangai, tabiat, watak, adab, agama, sifat asal, marwah, gambaran batin, dan atau budi pekerti' (Ahmat, 2001; Alfan, 2011; Gazalba, 1981). Menurut Alfan (2011), akhlak dalam bahasa Arab bermaksud sajiyyah 'perangai', mur'uah 'budi', thab 'in 'tabiat', dan adab 'sopan santun'.

Walaupun akhlak bagian dari etika, keduanya berbeda secara mendasar. Akhlak, berdasarkan ajaran Islam, dibentuk oleh rukun iman dan rukun Islam melalui proses ihsan, ikhlas, dan takwa (Gazalba, 1981). Sebaliknya, etika hanya berdasarkan akal-pikiran. Budi pekerti sama maknanya dengan akhlak dan budi yang baik akan melahirkan budi pekerti atau akhlak yang mulia.

\section{Landasan Teoretis}

Untuk menganalisis kelas semiotik karya yang dikaji, penelitian ini menggunakan teori semiotika. Semiotika adalah ilmu tentang sistem tanda (sign). Ilmu ini memiliki tradisi semenjak zaman Greek Stoics (Coble \& Jansz, 1999). Semiotika adalah teori mengenai tanda yang dikomunikasikan.

Pierce (1982) menganggap bahwa manusia berpikir dalam tanda (sign). Tanda merupakan suatu unsur dalam komunikasi. Fungsi esensial sebuah tanda adalah membuat relasi yang tak efisien menjadi efisien.

Komunikasi, pemikiran, dan pemahaman kita tentang apa pun di dunia ini menjadi efisien karena adanya tanda.

Berdasarkan ciri-ciri tanda, Zoest (1993) membuat simpulan: segala sesuatu dapat dianggap sebagai tanda. Syaratnya sesuatu itu dapat membuat hubungan segitiga dengan sebuah ground, sebuah denotatum, dan sebuah interpretant.

Menurut Peirce (Pateda, 2001; Sobur, 2006), tanda "is something wich stands to somebody for something in some respect or capacity." Sesuatu yang digunakan agar tanda dapat berfungsi, oleh Peirce, disebut ground. Konsekuensinya, tanda (sign atau representamen) selalu terdapat dalam hubungan triadik: ground, object, dan interpretant.

Tanda berhubung pula dengan denotatum. Menurut Zoest (1993), denotatum adalah kenyataan yang ditunjuk oleh tanda. Peirce membagi tiga jenis tanda berdasarkan sifat hubungan antara tanda dan denotatum-nya. Ketiga tanda tersebut adalah icon (ikon), index (indeks), dan symbol (simbol) (Zoest, 1993).

Ikon adalah tanda yang ada sebagai kemungkinan, tanpa tergantung pada adanya sesebuah denotatum, tetapi dapat dihubungkan dengan denotatum tertentu berdasarkan persamaan potensial yang dimilikinya. Peta, gambar (foto), dan lukisan adalah tanda ikonik karena ada hubungan persamaannya dengan denotatum-nya.

Indeks adalah tanda yang tergantung pada adanya sebuah denotatum. Dalam indeks, perhubungan antara tanda dan denotatum-nya bersebelahan. Segala sesuatu yang memusatkan perhatian pada sesuatu yang lain merupakan indeks: jari yang diacungkan, penunjuk arah mata angin, deheman penuh makna, dan katakata deiktis (di sini, hari ini, ini, dan lain-lain).

Simbol adalah tanda yang perhubungan antara tanda dan denotatum-nya ditentukan oleh peraturan yang berlaku umum. Simbol merupakan tanda yang dihubungkan dengan peraturan umum . Dengan demikian, tanda simbolik adalah tanda melalui perjanjian (Zoest, 
1993).

Berdasarkan pembedaan tanda-tanda, dapat dibuat tipologi tanda. Peirce membedakan sepuluh kelas tanda (Zoest, 1993). Pertama, qualisign atau lengkapnya qualisign ikonik rhematik, sifat 'kuning, biru, merah, putih' misalnya. Kedua, sinsign ikonik yang selalu merupakan rheme yaitu tanda yang menunjukkan kemiripan seperti gambar (foto), diagram, peta, dan tanda baca. Ketiga, sinsign indeksikal rhematik adalah tanda berdasarkan pengalaman langsung, yang secara langsung menarik perhatian karena kehadirannya disebabkan oleh sesuatu. Keempat, sinsign dicent yang selalu berupa indeksikal yaitu tanda yang memberikan informasi tentang sesuatu. Kelima, legisign ikonik yang selalu merupakan rheme yaitu tanda yang menginformasikan norma atau hukum. Keenam, legisign indeksikal rhematik yaitu tanda yang mengacu kepada objek tertentu, misalnya deiksis 'di sini, kini' terlepas dari konteks atau situasi. Ketujuh, legisign indeksikal dicent yaitu tandayang bermakna informasi dan menunjuk subjek informasi. Kedelapan, simbol rhematik yang selalu merupakan legisign yaitu tandayang dihubungkan dengan objeknya melalui asosiasi ide umum. Kesembilan, simbol dicent yang selalu merupakan legisign yaitu tanda yang langsung menghubungkan dengan objek melalui asosiasi dalam otak. Kesepuluh, argumen yang selalu merupakan simbol dan legisign yaitu tanda yang merupakan inferensi seseorang terhadap sesuatu berdasarkan alasan tertentu.

Menurut Eco (1976) dan Littlejohn (1996), dalam semiotika, tanda, objek, dan makna membina hubungan segitiga. Penanda mewakili objek yang menjadi petanda. Penerima menghubungkan tanda dengan objek dan makna sehingga menghasilkan interpretant, yang berfungsi sebagai perantara antara penanda dan petanda. Makna tanda wujud di dalam pikiran penerima setelah dia menghubungkan tanda dengan objek.

Dalam penelitian sastra dengan pendekatan semiotika, tanda indeks yang paling banyak dicari yaitu tanda yang menunjukkan hubungan sebab-akibat. Penelitian semiotika itu, menurut Preminger (1974), memandang objek-objek atau laku-laku sebagai parole (laku tuturan) dari suatu langue (bahasa: sistem linguistik) yang menjadi dasar tata bahasanya harus dianalisis.

\section{Metode Penelitian}

Penelitian ini menggunakan metode deskriptif kualitatif (Trocim, 2000). Data penelitian ini dikumpulkan dan dianalisis dengan menggunakan teknik analisis isi karena yang dianalisis adalah kandungan isi karya-karya Raja Ali Haji. Konsep yang dikaji adalah nilai pendidikan karakter yang akan ditemukan setelah dianalisis kandungan isi karya-karya tersebut.

Menurut Stephenson (2000), analisis isi adalah kajian yang dilakukan untuk menentukan keberadaan kata-kata atau konsep-konsep tertentu dalam teks atau serangkaian teks. Dalam penelitian ini yang dianalisis adalah keberadaan makna dan hubungan kata-kata dengan konsep nilai pendidikan karakter sesuai dengan kelas semiotiknya. Selanjutnya, ditarik simpulan yang berkaitan dengan amanat yang terdapat di dalam karya yang dianalisis.

Dari dua puluh karya Raja Ali Haji, hanya lima karya terpilih yang dianalisis dalam penelitian ini. Kelima karya itu adalah (1) Syair Abdul Muluk, disingkat SAM (Haji, 1989), (2) Gurindam Dua Belas, disingkat GDB (Haji, 1846), (3) Tsamarat al-Muhimmah, disingkat TAM (Haji, 2012), (4) Tuhfat al-Nafis, disingkat TAN (Ahmad \& Haji, 1982), dan (5) Syair Sinar Gemala Mustika Alam, disingkat SGMA (Malik \& Junus, 2000).

\section{Hasil dan Pembahasan}

Karya Raja Ali Haji mengandungi dua puluh satu nilai pendidikan karakter terhadap masyarakat (Malik \& Shanty, 2019). Nilai budi pekerti tersebut meliputi (1) memuliakan tamu, (2) teliti dan waspada, (3) jujur, (4) menjunjung adat/menaati hukum, (5) bekerja sama/tolongmenolong, (6) merasakan suka-duka bersama, (7) menghormati orang lain, (8) menjaga 
kerukunan, (9) membela masyarakat, (10) rela berkorban, (11) sayang-menyayangi, (12) bertimbang rasa, (13) terbuka terhadap kritik, (14) pandai bergaul, (15) tak suka mencela orang, (16) tak membuka aib orang, (17) adil kepada kawan, (18) tak membedakan martabat manusia, (19) musyawarah dan mufakat, (20) beramal jariah, dan (21) mengajak berbuat kebaikan. Jadi, kedua puluh satu nilai yang menjadi indeks itu seyogianya ada dalam diri setiap pribadi yang harus diterapkan ketika berhubungan dengan masyarakat.

Analisis kelas semiotik dapat menjelaskan cara Raja Ali Haji menyajikan nilainilai pendidikan karkater dalam karya-karyanya, terutama melalui penggunaan indeks. Selain itu, juga dapat diketahui faktor yang mendasari beliau mengemukakan nilai-nilai budi pekerti tersebut.

Dalam hubungannya dengan masyarakat, karya-karya Raja Ali Haji pertama-tama mengamanatkan manusia untuk memuliakan tamu. Dalam hal ini, orang yang menerima tamu seyogianya memuliakan tamunya.

Nilai pendidikan karakter memuliakan tamu di dalam pergaulan hidup bermasyarakat dikemukakan oleh Raja Ali Haji dalam karya SAM (Haji, 1989), antara lain, pada bait 39 . Berikut ini nukilan bait syairnya.

Oleh saudagar dipermuliakan

Disuruhnya duduk di atas hamparan

Segala dagangan dilihat sekalian

Berjenis-jenis kassah dan kattan

Bait syair di atas bercerita tentang saudagar Negeri Barbari menerima tamunya pedagang dari Negeri Hindustan, Bahauddin namanya, yang adalah juga paman Sultan Hindustan, Sultan Syihabuddin. Kedatangan tamu itu ke Negeri Barbari, khususnya ke rumah saudagar Barbari, disambut dengan sangat baik dan dipermuliakan oleh saudagar Negeri Barbari. Kemuliaan dan kehormatan itu dilambangkan dengan dipersilakannya pedagang Bahaudin duduk di hamparan permadani.

Di dalam tamadun Melayu-Islam salah satu tanda tuan rumah menghormati tamunya adalah dengan menyambut tamu tersebut dengan baik, yang antara lain, memberikan tempat duduk yang terbaik yang dimiliki oleh tuan rumah. Selain itu, biasanya disediakan minuman dan juadah, yang juga terbaik, sesuai dengan kemampuan atau kesanggupan si penerima tamu. Kesemuanya itu dilakukan oleh tuan rumah demi memuliakan tamunya dan supaya terjalin silaturrahim di antara mereka, yang pada gilirannya terciptalah kesan yang baik. Atas dasar kehormatan dan kemuliaan itulah, bait SAM di atas menggunakan indeks hamparan (permadani) yang disediakan sebagai tempat duduk tamu saudagar Negeri Barbari, yakni pedagang kain dari Negeri Hindustan. Penyambutan yang baik terhadap tamunya itu menjadi indeks kehalusan budi pekerti saudagar Negeri Barbari dalam hubungannya dengan masyarakat, dalam hal ini tamunya. Hal itu berarti kemuliaan yang diberikan oleh tuan rumah kepada tamunya sesungguhnya merupakan cerminan kemuliaan si tuan rumah itu sendiri. Kebaikannya tak hanya dinikmati oleh si tamu, tetapi lebih-lebih akan dipancarkan serinya kepada si tuan rumah itu sendiri.

Karya TAN juga mengemukakan amanat memuliakan tamu. Perkara itu terdapat di hlm. 184, prf. 2 dan hlm. 185, prf 1. Berikut ini disajikan petikannya.

"Syahadan apabila selesailah muafakat itu maka Raja Haji serta paduka adinda Raja Sa'id dan Suliwatang pun berlayarlah ke Kedah. Maka singgahlah Engku Kelana di Perak hendak berjumpa Yang Dipertuan Perak. Maka dipermuliakanlah oleh Yang Dipertuan Perak serta diperjamunya makan minum. Maka tiada berapa hari di Perak maka bermohonlah kepada Yang Dipertuan Perak dan kepada paduka kekanda Yang Dipertuan Selangor. Adapun Yang Dipertuan Selangor tinggallah di Perak dahulu kerana belum tentu paduka adinda berperang," (Ahmad \& Haji, 1982).

Kutipan di atas merupakan kisah tentang Raja Haji (Kelana atau Wakil Yang Dipertuan Muda Kesultanan Riau-Lingga-Johor-Pahang) dan Sultan Selangor berkunjung ke Negeri Kedah. Sebelum sampai di Kedah, mereka singgah terlebih dahulu di Negeri Perak. 
Sesampainya di Perak, mereka dipermuliakan dan diperjamu oleh Baginda Sultan Perak.

Dari karya-karya Raja Ali Haji yang dikutip di atas dapatlah dibuat simpulan bahwa perilaku memuliakan tamu dalam pergaulan hidup bermasyarakat tergolong mulia dan terpuji. Watak dan perilaku itu merupakan indeks nilai pendidikan karakter yang harus diterapkan manusia dalam berhubungan dengan masyarakat.

Berdasarkan analisis di atas, kelas semiotik nilai pendidikan karakter terhadap masyarakat yang terdapat dalam karya Raja Ali Haji terdiri atas empat kelas. Ini bermakna tak semua dari sepuluh kelas tanda semiotik yang dikemukakan oleh Peirce (Zoest, 1993) terdapat dalam karya Raja Ali Haji.

Sifat, sikap, dan perilaku memuliakan tamu yang ditunjukkan oleh saudagar Negeri Barbari dalam SAM, bait 3 dan Yang Dipertuan Perak dalam TAN, hlm. 184-185 memang sedia ada atau melekat dalam diri mereka. Sifat dan sikap itu tergambarkan dari perbuatan menyambut tamu mereka masing-masing. Dengan demikian, sifat dan perbuatan memuliakan tamu merupakan kualitas baik yang dimiliki oleh para tokoh tersebut. Pemerian tentang sifat dan perilaku memuliakan tamu di dalam kedua karya itu tergolong ke dalam kelas semiotik qualisign ikonik rhematik.

Sifat, sikap, dan perbuatan memuliakan tamu yang ditunjukkan oleh para tokoh itu juga tergolong ke dalam kelas semiotik sinsign indeksikal rhematik. Kualitas budi pekerti yang

Tabel 1. Kelas Semiotik Nilai Pendidikan Karakter terhadap Masyarakat dalam Karya Raja Ali Haji

\begin{tabular}{|c|c|c|c|c|c|}
\hline \multirow[b]{2}{*}{ No. } & \multirow[b]{2}{*}{ Indeks } & \multicolumn{4}{|c|}{ Kelas Semiotik } \\
\hline & & Kelas I & Kelas II & Kelas III & Kelas IV \\
\hline 1 & 2 & 3 & 4 & 5 & 6 \\
\hline 1. & Memuliakan tamu & $\sqrt{ }$ & $\sqrt{ }$ & $\sqrt{ }$ & $\sqrt{ }$ \\
\hline 2. & Teliti dan waspada & $\sqrt{ }$ & $\sqrt{ }$ & $\sqrt{ }$ & $\sqrt{ }$ \\
\hline 3. & Jujur & $\sqrt{ }$ & $\sqrt{ }$ & $\sqrt{ }$ & $\sqrt{ }$ \\
\hline 4. & $\begin{array}{l}\text { Menjunjung } \\
\text { adat/menaati } \\
\text { hukum }\end{array}$ & $\sqrt{ }$ & $\sqrt{ }$ & $\sqrt{ }$ & - \\
\hline 5. & $\begin{array}{l}\text { Bekerja } \\
\text { sama/tolong- } \\
\text { menolong }\end{array}$ & $\sqrt{ }$ & $\sqrt{ }$ & $\sqrt{ }$ & - \\
\hline 6. & Merasakan suka- & $\sqrt{ }$ & $\sqrt{ }$ & $\sqrt{ }$ & - \\
\hline
\end{tabular}

mereka miliki itu dapat dilihat, diamati, dan didengar oleh orang lain, baik perkataan maupun perbuatan. Dengan demikian, kualitas itu memang ada di dalam diri mereka.

Nilai pendidikan karakter memuliakan tamu dalam SAM dan TAN juga dikemukakan dengan menggunakan kelas semiotik legisign indeksikal dicent. Dalam hal ini, kualitas itu diungkapkan berdasarkan norma atau peraturan diyakini oleh Raja Ali Haji, yakni ajaran agama Islam (Al-Quran, Surah Yusuf, ayat 58-59 dan Hadits yang diriwayatkan oleh Muttafaq 'Alaih).

Di dalam SAM, bait 39, baris 1 juga terdapat simpulan Raja Ali Haji tentang nilai pendidikan memuliakan tamu, "Oleh saudagar dipermuliakan." Hal yang sama terdapat di dalam TAN (Matheson, 1982), "Maka dipermuliakanlah oleh Yang Dipertuan Perak ..." Hal itu berarti pemerian nilai pendidikan karakter memuliakan tamu juga menggunakan kelas semiotik argumen.

Berdasarkan uraian di atas, nilai pendidikan karaketer memuliakan tamu dalam pergaulan hidup bermasyarakat dikemukakan oleh Raja Ali Haji dengan menggunakan empat kelas tanda semiotik, yakni qualisign ikonik rhematik, sinsign indeksikal rhematik, legisign indeksikal dicent, dan argumen. Secara lengkap, kelas semiotik nilai pendidikan karakter terhadap masyarakat yang ditemukan dalam karya Raja Ali Haji disajikan pada Tabel 1 berikut ini. 
JURNAL KIPRAH. November 2019; 7 (2): 71-80

ISSN (online): 2580-6947

ISSN (print): 2354-7278

\begin{tabular}{|c|c|c|c|c|c|}
\hline & duka bersama & & & & \\
\hline 7. & $\begin{array}{l}\text { Menghormati } \\
\text { orang lain }\end{array}$ & $\sqrt{ }$ & $\sqrt{ }$ & $\sqrt{ }$ & - \\
\hline 8. & $\begin{array}{l}\text { Menjaga } \\
\text { kerukunan }\end{array}$ & $\sqrt{ }$ & $\sqrt{ }$ & $\sqrt{ }$ & - \\
\hline 9. & $\begin{array}{l}\text { Membela } \\
\text { masyarakat }\end{array}$ & $\sqrt{ }$ & $\sqrt{ }$ & $\sqrt{ }$ & - \\
\hline 10. & Rela berkorban & $\sqrt{ }$ & $\sqrt{ }$ & $\sqrt{ }$ & $\sqrt{ }$ \\
\hline 11. & $\begin{array}{l}\text { Sayang- } \\
\text { menyayangi }\end{array}$ & $\sqrt{ }$ & $\sqrt{ }$ & $\sqrt{ }$ & - \\
\hline 12. & $\begin{array}{l}\text { Bertimbang rasa } \\
\text { (empati) }\end{array}$ & $\sqrt{ }$ & $\sqrt{ }$ & $\sqrt{ }$ & - \\
\hline 13. & $\begin{array}{l}\text { Terbuka terhadap } \\
\text { kritik }\end{array}$ & - & - & $\sqrt{ }$ & $\sqrt{ }$ \\
\hline 14. & Pandai bergaul & - & - & $\sqrt{ }$ & $\sqrt{ }$ \\
\hline 15. & $\begin{array}{l}\text { Tak suka mencela } \\
\text { orang }\end{array}$ & - & - & $\sqrt{ }$ & $\sqrt{ }$ \\
\hline 16. & $\begin{array}{l}\text { Tak membuka aib } \\
\text { orang }\end{array}$ & - & - & $\sqrt{ }$ & $\sqrt{ }$ \\
\hline 17. & Adil kepada kawan & - & - & $\sqrt{ }$ & $\sqrt{ }$ \\
\hline 18. & $\begin{array}{l}\text { Tak membedakan } \\
\text { martabat manusia }\end{array}$ & - & - & $\sqrt{ }$ & $\sqrt{ }$ \\
\hline 19. & $\begin{array}{l}\text { Musyawarah dan } \\
\text { mufakat }\end{array}$ & - & - & $\sqrt{ }$ & $\sqrt{ }$ \\
\hline 20. & Beramal jariah & $\sqrt{ }$ & $\sqrt{ }$ & $\sqrt{ }$ & - \\
\hline 21. & $\begin{array}{l}\text { Mengajak berbuat } \\
\text { kebaikan }\end{array}$ & - & - & $\sqrt{ }$ & $\sqrt{ }$ \\
\hline
\end{tabular}

\section{Keterangan:}

Kelas I = qualisign ikonik rhematik

Kelas II = sinsign indeksikal rhematik

Kelas III = legisign indeksikal dicent

Kelas IV $=$ argumen

$\sqrt{ } \quad=$ ada

- $\quad$ = tak ada

Tabel 1 menunjukkan bahwa nilai pendidikan karakter terhadap masyarakat dalam karya Raja Ali Haji menggunakan empat kelas semiotik: qualisign ikonik rhematik, sinsign indeksikal rhematik, legisign indeksikal dicent, dan argumen. Akan tetapi, tak semua kelas semiotik itu hadir dalam setiap nilai pendidikan karakter yang dikemukakan. Hal itu disebabkan oleh kelas-kelas semiotik tersebar secara acak di dalam kedua puluh satu nilai pendidikan karakter yang dikemukakan penulisnya.

Di antara keempat kelas tanda semiotik itu, hanya legisign indeksikal dicent yang terdapat dalam semua nilai pendidikan karakter yang dikemukakan. Hal itu disebabkan oleh semua nilai budi pekerti itu merujuk kepada norma atau peraturan ajaran Islam yang mendasari karya Raja Ali Haji sekaligus nilainilai ajaran Islam itulah yang diyakininya.

\section{Kesimpulan}

Karya Raja Ali Haji mengandungi dua puluh satu nilai pendidikan karakter terhadap masyarakat. Nilai-nilai pendidikan karakter itu terdiri atas empat kelas. Pertama, qualisignikonik rhematik yaitu kualitas pikiran, perasaan, sifat, dan sikap yang sedia ada atau melekat pada orang yang memiliki karakter itu. Kedua, sinsign 
indeksikal rhematik yaitu kualitas perkataan dan atau perilaku seseorang yang dapat didengar dan atau diamati oleh orang lain. Ketiga, legisign indeksikal dicent yaitu tanda yang bermakna informasi dan merujuk kepada subjek informasi berdasarkan norma atau ajaran agama Islam. Keempat, argumen yaitu simpulan yang dikemukakan oleh Raja Ali Haji sendiri berdasarkan kebenaran yang beliau yakini, yakni norma ajaran Islam. Dengan demikian, manusia yang memiliki dua puluh satu nilai terhadap masyarakat itu tergolong manusia yang berkarakter atau berbudi pekerti yang baik atau berakhlak mulia. Hal itu berarti bahwa karya Raja Ali Haji dapat dan sebaiknya dijadikan materi pembelajaran pendidikan karakter dan pendidikan sastra yang bersumber dari ajaran Islam untuk memperkokoh karakter bangsa Indonesia, khususnya generasi muda. Bahkan, karena nilainya bersifat universal, nilai-nilai pendidikan karakter yang dikemukakan oleh Raja Ali Haji itu juga dapat dirujukoleh semua bangsa di dunia ini untuk dijadikan pedoman hidup.

\section{Referensi}

Ahmad, R., \& Haji, R. A. (1982). Tuhfat al-nafis. In Virginia Matheson (Ed.). Petaling Jaya, Malaysia: Penerbit Fajar Bakti Sdn. Bhd.

Ahmat, Z. (2001). Falsafah etika masyarakat Melayu tradisional: Suatu kajian berdasarkan pantun Melayu. Disertasi Ijazah Sarjana Sastera, Jabatan Pengajian Media. Universiti Malaya, Kuala Lumpur, Malaysia.

Alfan, M. (2011). Filsafat etika Islam. Bandung, Indonesia: Pustaka Setia.

Bachmid, A. (2005). Aktualisasi nialai-nilai Islam dalam "Gurindam Dua Belas" karya Raja Ali Haji (Telaah teks sastra Melayu abad xix). Jurnal Al-Turats, 3(11), 201219.

Braginsky, V. (1994). Erti keindahan dan keindahan sert dalam kesusastraan Melayu klasik. Kuala Lumpur, Malaysia: Dewan Bahasa dan Pustaka.

Coble, P., \& Jansz, L. (1999). Introducing semiotics. New York, USA: Icon BooksTotem Books.
Eco, U. (1976). A theory of semiotics. Bloomington: Indiana University Press.

Gazalba, S. (1981). Sistematika filsafat: Buku iv. Jakarta, Indonesia: NV Bulan Bintang.

Haji, R. (1987). Kitab pengetahuan bahasa: Kamus logat Melayu Johor, Pahang, Riau, dan Lingga. In Yunus, R.H. Pekanbaru, Indonesia: Bagian Proyek Penelitian dan Pengkajian Kebudayaan Melayu, Penelitian dan Pengkajian Kebudayaan Nusantara, Departemen Pendidikan dan Kebudayaan.

Haji, R. A. (1846). Gurindam dua belas. Batavia, Indonesia.

Haji, R. A. (1989). Syair Abdul Muluk. In $S$. Syamsir (Ed.) (p. Haji, R. A. (1988). Syair Abdul Muluk (S. Syamsir,). Pekanbaru, Indonesia: Bagian Proyek Penelitian dan Pengkajian Kebudayaan Melayu, Penelitian dan Pengkajian Kebudayaan Nusantara, Departemen Pendidikan dan Kebudayaan.

Haji, R. A. (2012). Tsamarat al-muhimmah. In Malik, A. (Ed.). Depok, Indonesia: Komodo Books.

Littlejohn, S. W. (1996). Theories of human communication. New York, USA: Wadsworth Publishing Company.

Malik, A. (2008). Menelusuri tempat asal bahasa Indonesia. Retrieved January 5, 2018, from December 11 website: http://www.rajaalihaji.com

Malik, A. (2012a). Menjemput tuah menjunjung marwah. Depok, Indonesia: Komodo Books.

Malik, A. (2012b). Nilai-nilai budi pekerti di dalam karya-karya Raja Ali Haji. Tanjungpinang, Indonesia.

Malik, A. (2015). Kehalusan Budi dalam Karya Raja Ali Haji. Universiti Pendidikan Sultan Idris, Perak, Malaysia.

Malik, A., \& Junus, H. (2000). Studi tentang himpunan karya Raja Ali Haji. Pekanbaru, Indonesia: Badan Perencanaan Pembangunan Daerah, Propinsi Riau dan Pusat Penelitian Kebudayaan dan Kemasyarakatan.

Malik, A., \& Shanty, I. L. (2017). Indeks Budi Pekerti Peribadi Dalam Karya Raja Ali Haji. Jurnal Kiprah, 5(2), 1-21.

Malik, A., \& Shanty, I. L. (2019). Character Indexes of the People in the Works of Raja Ali Haji. 295(ICETeP 2018), 148-151. https://doi.org/10.2991/icetep-18.2019.36

Matheson, V. (1982). Tuhfat al-nafis. Petaling 
JURNAL KIPRAH. November 2019; 7 (2): 71-80

ISSN (online): 2580-6947

ISSN (print): 2354-7278

Jaya, Malaysia: Penerbit Fajar Bakti Sdn. Bhd.

Osborn, R., \& Van Loon, B. (1996). Ancient eastern philosophy for beginners. Cambridge: Icon Book Ltd.

Pateda, M. (2001). Semantik leksikal. Jakarta, Indonesia: Rineka Cipta.

Pierce, C. S. (1982). Logic as semiotics: The theory of signs. In R. E. Innis, Semiotics: An introduction anthology. Bloomington: Indiana University Press.

Preminger, A. (1974). Princeton encyclopedia of poetry and poetics. London, England: The Maxmillan Press Ltd.

Pusat Kurikulum. (2010). Pengembangan pendidikan budaya dan karakter bangsa: Pedoman sekolah. Jakarta, Indonesia: Badan Penelitian dan Pengembangan, Kementerian Pendidikan Nasional.

Rahman, J. D., Azhar, A., Sarjono, A. R., \& Hafrizal, R. M. (2010). Dermaga sastra Indonesia: Kepengarangan Tanjungpinang dari Raja Ali Haji hingga Suryatati A. Manan. Depok, Indonesia: Komodo Books.

Sobur, A. (2006). Semiotika komunikasi. Bandung, Indonesia: Remaja Rosdakarya.

Stephenson, M. S. (2000). Analisis isi (Translated by Diah, M.). Pekanbaru, Indonesia: Balai Bahasa Pekanbaru, Pusat Bahasa, Departemen Pendidikan Nasional.

Trocim, W. K. (2000). Penelitian kualitatif (Translated by Diah, M.). Pekanbaru, Indonesia: Balai Bahasa Pekanbaru, Pusat Bahasa, Departemen Pendidikan Nasional.

Yazdi, M. T. M. (2012). 22 nasihat abadi penghalus budi. Jakarta, Indonesia: Citra.

Zoest, A. Van. (1993). Semiotika: tentang tanda, cara kerjanya, dan apa yang kita lakukan dengannya (Translated by Soekowati, A.). Jakarta, Indonesia: Yayasan Sumber Agung.

Zuriah, N. (2008). Pendidikan moral dan budi pekerti dalam perspektif perubahan. Jakarta, Indonesia: Bumi Aksara. 